\title{
Therapeutic Assessment of Dried Rumen Liquor Preparations in Cases of Simple Indigestion in Buffaloes
}

\author{
Arpit Tyagi $^{1}$, Richa Arora ${ }^{2}$, S.Shekhar ${ }^{3}$, V.S. Rajora ${ }^{1}$ and Niddhi Arora ${ }^{1}$ \\ ${ }^{1}$ Department of Veterinary Medicine, CVASc., GBPUAT,, Pantnagar, U.K, India \\ ${ }^{2}$ Department of Animal Biotechnology, IVRI, Izatnagar, Bareilly, U.P., India \\ ${ }^{3}$ Veterinary Science, Krishi Vigyan Kendra (ICAR-NRRI), Koderma, Jharkhand, India \\ *Corresponding author
}

\begin{tabular}{|c|}
\hline Keywords \\
\hline $\begin{array}{l}\text { Indigestion, } \\
\text { Rumen, Blood, } \\
\text { Biochemical, } \\
\text { Buffaloes }\end{array}$ \\
\hline Article Info \\
\hline $\begin{array}{l}\text { Accepted: } \\
26 \text { June } 2018 \\
\text { Available Online: } \\
10 \text { July } 2018\end{array}$ \\
\hline
\end{tabular}

\section{Introduction}

India is an agriculture based country and livestock sector is one of the most important components of agriculture in India. The contribution of livestock sector through a series of revolution like Green, White, Blue and Pink has been tremendous in transformation of national economy. It has given sustainability and stability to our economy. The buffalo (Bubalus bubalis) forms the backbone of India's dairy industry and is considered as India's milking machine (Balain, 1999). The world's buffalo population has been estimated to be about 185.29 million, and of these more than 57\% i.e. 105 millions are in India. This large population of buffaloes contributes more than half of total milk produced in India. Buffalo makes one-third of the bovine population in the country (DAHD, 2014). These animals require a relatively low level of inputs in the predominantly mixed farming systems and are well known for their ability to thrive on low 
quality crop residues and green forage under harsh climatic conditions (Resali, 2000). Furthermore, the contributions of milk, meat, manure and draught power of the buffalo to the overall national economy have been overwhelming (Shrestha and Shrestha, 1998).

Rumen disorders are of a greater clinical interest as they affect large number of animals and incur great losses in both production and cost of treatment of the affected ruminants (Ratib, 2001). The most common ruminal disorders such as tympany, indigestion and impaction are characterized by poor appetite, altered $\mathrm{pH}$, reduced rumen motility and decreased microbial counts ultimately resulting in decreased milk production. Sudden change in the feed is the most common cause of indigestion in ruminants. Other factors include feeding spoiled and moulded feeds, use of antibiotics especially via oral route, sudden changes in climatic conditions also cause indigestion (Radostits et al., 2006). Mild simple indigestion is selflimiting in nature. Reduced appetite is one of the early clinical signs seen in case of indigestion while subsequent prominent symptoms include anorexia, depression, reduced or completes cessation of rumination and eructation, decreased reticulo-ruminal movements and significant reduction in bacterial and protozoal counts (Garry, 2002). Indigestion also leads to hepatic disturbances and reduced milk production in affected animals (Singh et al., 1996). The ultimate result of these clinical conditions is production and economic losses to the farmers. As temperature have significant effects on ruminal fermentation patterns and gas production (Bhatta et al., 2006), ruminants are more likely to suffer from ruminal disorders.

In India, the ruminal contents produced from slaughter of animals in abattoirs are not used and get rid of it to constitute a great source of environmental pollution. It is a well established fact that cud transplantation from healthy animal is still the best treatment for chronic indigestion in ruminants. However, it is not always possible to get cud from healthy animal that too in large quantities. So this study is conducted to investigate the influence of air dried and lyophilized ruminal liquor on treatment of indigestion in buffaloes and to find an acceptable useful technique for hygienic disposal, preservation and recycling of these important materials to be reused for treatment of stomach upset in buffaloes. Additionally to overcome the risk of drenching pneumonia by air drying and freeze-drying of rumen liquor to overcome the issues of handling of fresh rumen liquor. The present study was conducted to develop dried and lyophilized rumen liquor preparations for therapeutic management of simple indigestion in buffaloes.

\section{Materials and Methods}

The present study was undertaken in the Department of Veterinary Medicine, Teaching Veterinary Clinical Complex and Instructional Dairy Farm, C.V.A.Sc., GBPUA\&T, Pantnagar (Coordinates: $28.97^{\circ} \mathrm{N}, 79.41^{\circ} \mathrm{E}$ ), U.S. Nagar (Uttarakhand, India). A total of 24 buffaloes were included in the study out of which 18 were suffering from simple indigestion whereas 6 healthy buffaloes served as healthy control. The alterations in clinical parameters, rumen liquor characteristics and hemato-biochemical parameters were recorded. Buffaloes of healthy control group constitute "Group A", whereas buffaloes suffering from simple indigestion were divided in 3 groups consisting of 6 buffaloes in each group. These groups were named as "Group B" for those treated with Magnesium sulphate, "Group C" for those treated with Air dried rumen liquor (AD-RL) and "Group D" for those treated with lyophilized rumen liquor (L-RL). 


\section{Preparation of therapeutic agents}

\section{Procurement of rumen liquor}

Rumen liquor was procured from Government Slaughter House, Haldwani, Uttarakahnd into insulated thermos container, flushed with $\mathrm{CO}_{2}$, a thin layer of liquid Paraffin was added and then sealed before being transported to the Department of Veterinary Medicine, C.V.A.Sc., GBPUA\&T, Pantnagar. Then rumen liquor was strained through four layer of muslin cloth and then subjected to drying and lyophilisation.

\section{Preparation of Air Dried rumen liquor}

Strained rumen liquor was kept forming a thin layer in enamel and glass treys at room temperature for drying. Drying was done till dried rumen liquor showed no significant variation in weight even after $24 \mathrm{hrs}$ of exposure to room temperature. On an average it took seven and half days ranging from 5 to 14 days for adequate drying depending on environmental temperature, relative humidity and surface area provided for evaporation. On an average $100 \mathrm{ml}$ of strained rumen liquor yielded 3.163 grams of dried rumen liquor powder i.e. $31.63 \mathrm{mg}$ of dried rumen liquor was equivalent to $1 \mathrm{ml}$ of fresh strained rumen liquor.

\section{Preparation of Lyophilized rumen liquor}

Strained fluid was placed in lyophilizer flasks, flooded with $\mathrm{CO}_{2}$ and sealed with parafilm. Rumen fluid was slowly frozen by placing the flasks in a conventional freezer at $-20^{\circ} \mathrm{C}$. After freezing lyophilisation was done with the help of lyophilizer at Department of Veterinary Medicine, C.V.A.Sc., GBPUA\&T, Pantnagar. Lyophilisation was done till lyophilized rumen liquor showed no significant variation in weight even after an hour of exposure to lyophilizer. It took about $24 \mathrm{hrs}$ for adequate drying. On adequate drying it was found that $27.82 \mathrm{mg}$ of lyophilized rumen liquor was equivalent to $1 \mathrm{ml}$ of fresh strained rumen liquor.

\section{Clinico-pathological studies}

\section{Clinical Observations}

The clinical observations included recording of rectal temperature, heart rate, respiration rate and ruminal movements. Rectal temperature was measured by using a clinical mercury thermometer and expressed in ${ }^{\circ} \mathrm{C}$; pulse rate was recorded over the middle coccygeal artery at a point on the underside of the base of the tail by applying gentle digital pressure to feel the arterial pulsation, expressed as per minute. Heart and respiration rates were recorded during auscultation over chest area using a stethoscope. Ruminal motility was detected at the left para-lumbar fossa by using back of the closed fist applying sufficient pressure to overcome the muscular tone. Ruminal movements were carefully recorded for 5 minutes.

\section{Rumen liquor examination}

About $250 \mathrm{ml}$ of ruminal fluid samples were collected from each buffalo under study using stomach tube with a conical flask connected to its free end, while a vacuum pump was connected to the side tube of the flask.

Rumen liquor $\mathrm{pH}$ was measured immediately after collection of samples using a calibrated electronic digital portable $\mathrm{pH}$ meter. Methylene Blue Reduction Test (MBRT), Sedimentation Activity Test (SAT) and Nitrate reduction test were performed by method described by Sharma (2009) and their results were expressed in minutes. Estimation of Total Volatile Fatty Acid (T.V.F.A.) was done by method as described by Sharma, (2009) and results were expressed as 
millimoles $/ \mathrm{ml}$. Total protozoal and bacterial count were performed by method described by Chakrabarti (2006) and protozoal motility was described as +++ (abundant and highly motile$85-95 \%),++$ (moderate in number and motile$65-75 \%),+($ low in number and sluggish- 25$45 \%), \pm$ (no or sporadic alive protozoa) and (dead protozoa) (Fouda, 1995).

\section{Haemato- biochemical studies}

About $10.0 \mathrm{ml}$ of venous blood sample was collected using dry disposable syringe through the jugular vein from each buffalo and immediately after collection about $3.0 \mathrm{ml}$ blood was transferred to EDTA (@ $1.5 \mathrm{mg} / \mathrm{ml}$ ) vials for complete blood count (CBC) that was carried out within two hours of collection. Remaining about $7.0 \mathrm{ml}$ of blood was transferred in to a clean and dry test tube without any anticoagulant and was allowed to clot in slanting position for about one hour and then separated serum was harvested gently after centrifugation for 10 minutes at 3,000 rpm. The supernatant serum was collected carefully in a dry Eppendrof tubes with the help of micropipette and finally the well labelled sera samples was be preserved at $20^{\circ} \mathrm{C}$ in a deep freeze for further biochemical and serological estimation.

Haematological studies were conducted to study the effect of indigestion on blood cellular profiles and it was compared with profile of apparently healthy normal buffaloes. Haematological parameters viz. haemoglobin, packed cell volume (PCV), total erythrocyte count (TEC), total leukocyte count (TLC), differential leukocyte count (DLC) and red cell indices viz. MCV, $\mathrm{MCH}$ and $\mathrm{MCHC}$ were studied as per standard laboratory procedures described by Jain (1986).

Biochemical parameters viz. Alaninie amino transferase (ALT), aspartate amino transferase (AST), lactate dehydrogenase (LDH), serum glucose, total serum cholesterol, total serum proteins, blood urea nitrogen (BUN), serum calcium and serum phosphorus were determined using the non-haemolysed serum obtained from the blood samples using diagnostic kits from Erba diagnostics Mannheim, Germany.

\section{Therapy evaluation}

The efficacy of the therapy to treat indigestion in buffaloes was assessed by-

The score recorded by dividing the number of cases recovered on each day by the number of indigestion cases on the previous days.

\section{Statistical analysis}

The data was presented as Mean \pm standard deviation (SD). Paired t-test was used for comparing means using Students t-test. Statistical Package for Social Science (SPSS) $17.0 \mathrm{v}$ was used for the analysis. The level of significance was set at $\mathrm{P}<0.05$.

\section{Results and Discussion}

The results of clinical examination and physiological data are presented in table 1 . The buffaloes in all the three treatment groups showed significantly $(\mathrm{p}<0.05)$ reduced rumen motility and $\mathrm{pH}$ before treatment compared with control animals. After treatment with Magnesium sulphate, AD-RL and L-RL in respective groups, a significant $(\mathrm{p}<0.05)$ increase in rumen motility was observed in all groups but was lower than normal animals of healthy control group. All the treatments were successful in normalizing the rumen $\mathrm{pH}$ towards normal range. Quantitative analysis of rumen liquor, revealed that buffaloes suffering from simple indigestion showed significantly $(\mathrm{p}<0.05)$ higher SAT, MBRT, NRT and significantly $\quad(\mathrm{p}<0.05) \quad$ lower TVFA concentration, total protozoa count and total bacterial count compared to control animals. Qualitative examination of the rumen fluid for 
protozoan motility showed significant $(p<0.05)$ decrease in motility scores before treatment compared to control group. Treatment with Magnesium sulphate, AD-RL and L-RL significantly $(\mathrm{p}<0.05)$ reduced SAT and NRT and significantly $(\mathrm{p}<0.05)$ increased total protozoa count, total bacterial count and protozoal motility in the respective treatment groups. However, treatment with AD-RL and L-RL succeeded in normalizing the MBRT and TVFA production comparable to that of control animals.

Haemato-biochemical profile is presented in table 2. Animals suffering from simple indigestion showed no change in haemoglobin concentration and PCV values. However, haematological findings, prior to treatment revealed leukocytosis, neutrophilia and lymphocytopenia. All the treatments were successful in normalizing the TLC towards normal range. However, only L-RL was able to significantly $(\mathrm{p}<0.05)$ lower neutrophil count. Buffaloes suffering from simple indigestion showed significantly $(\mathrm{p}<0.05)$ higher serum ALT, AST, LDH and BUN and significantly $(p<0.05)$ lower serum glucose level compared to healthy control buffaloes. All the treatment regimens significantly $(\mathrm{p}<0.05)$ decreased serum ALT, AST, LDH and BUN and significantly $(\mathrm{p}<0.05)$ increased glucose in respective groups. Furthermore, no alteration in values of serum cholesterol, total serum proteins, serum calcium and phosphorous were recorded.

All the buffaloes in treatment groups Air dried RL and Lyophilized RL recovered by final day of observation. However, in Group treated with $\mathrm{MgSO}_{4} 5$ out of 6 buffaloes showed recovery. Recovery was indicated by restoration of normal appetite and rumination. Based on the therapeutic evaluation score, Group treated with Lyophilized RL showed higher and faster recovery rates than other therapeutic groups, followed by Groups treated with Air dried RL and $\mathrm{MgSO}_{4}$. No adverse reaction was observed in any of the treatment groups during the trial period (Table $3)$.

In this study, buffaloes suffering with simple indigestion showed reduced rumen motility, protozoal and bacterial counts, protozoal motility and TVFA production. There was an increase in SAT, MBRT and nitrate reduction test. Even though, primary atony caused by dietary abnormality is difficult to explain. Changes in the $\mathrm{pH}$ of its contents markedly affect the motility of the rumen and in cases caused by overeating on grain an increase in acidity is probably of importance. High protein diets, including the feeding of excessively large quantities of legumes or urea, also depress motility because of the sharp increase in alkalinity that results. Atony that occurs after feeding on damaged feeds may have the same basis or be due to other unidentified agents in the food. The simple accumulation of indigestible food may physically impede ruminal activity. Putrefaction of protein may also play a part in the production of atony. The toxic amides and amines produced may include histamine, are known to cause ruminal atony. Histamine may contribute to the ruminal atony that occurs in allergy, or after heavy grain feeding, but the absorption of histamine from the forestomachs in any circumstances is probably very limited (Radostits et al., 2006). In this study, rumen $\mathrm{pH}$ was slightly acidic in buffaloes suffering from simple indigestion. Garry (2002) had stated that in simple indigestion, $\mathrm{pH}$ changes were mild and tend towards acidosis or alkalosis. The decrease in the rumen liquor $\mathrm{pH}$ was due to production of lactic acid in rumen, as a result of increase in lactic acid fermenting bacteria and regeneration microflora. Increased MBRT indicated decreased microbial fermentation in rumen due to inactive microflora and fauna. Increased SAT indicates decreased microbial activity (Garry, 
2002) and suppressed microbial fermentation (Nicholas and Penn, 1958). Time taken to reduce nitrate will increase in cases of indigestion due to reduced microbial activity (Sharma, 2009). As a consequence for reduced microflora and fauna activity, the TVFA production was decreased (Singh et al., 1996). Rumen $\mathrm{pH}$ had been reported to be one of the most valuable ecological factors influencing the microbial population in the rumen. The protozoan motility decreases whenever there is a reduction in rumen $\mathrm{pH}$ (Steen, 2001) and during underfeeding or starvation (Dirksen, 1969). Large entodiniomorphs are more sensitive to change in $\mathrm{pH}$. Small trichostomatids (holotrichs) tend to be most tolerant. However, below pH 5.0, all protozoa die (Belknap and Navarre, 2000).

Table.1 Ruminal parameters in different groups $[\mathrm{Mean} \pm \mathrm{SE}]$

\begin{tabular}{|l|c|c|c|c|c|}
\hline Parameter & Day & $\begin{array}{c}\text { Healthy control } \\
\text { (A) }\end{array}$ & $\begin{array}{c}\mathrm{MgSO}_{4} \\
(\mathrm{~B})\end{array}$ & $\begin{array}{c}\text { Air dried RL } \\
(\mathrm{C})\end{array}$ & $\begin{array}{c}\text { Lyophilize RL } \\
(\mathrm{D})\end{array}$ \\
\hline $\begin{array}{l}\text { Rumen motility } \\
\text { (per 5 min.) }\end{array}$ & 0 & $7.00 \pm 0.54$ & $1.33 \pm 0.52^{\mathrm{a}}$ & $1.00 \pm 0.89^{\mathrm{a}}$ & $1.00 \pm 0.63^{\mathrm{a}}$ \\
\hline Rumen Ph & 5 & $7.50 \pm 0.85$ & $3.00 \pm 0.63$ & $5.00 \pm 1.41^{\mathrm{A}}$ & $6.33 \pm 1.21^{\mathrm{A}}$ \\
\hline & 0 & $6.94 \pm 0.07$ & $6.19 \pm 0.09^{\mathrm{a}}$ & $6.14 \pm 0.08^{\mathrm{a}}$ & $6.21 \pm 0.12^{\mathrm{a}}$ \\
\hline $\begin{array}{l}\text { MBRT } \\
\text { (MIN.) }\end{array}$ & 5 & $6.95 \pm 0.06$ & $6.73 \pm 0.06$ & $6.88 \pm 0.06^{\mathrm{A}}$ & $6.99 \pm 0.07^{\mathrm{A}}$ \\
\hline $\begin{array}{l}\text { SAT } \\
(\text { MIN.) }\end{array}$ & 5 & $5.78 \pm 0.93$ & $10.82 \pm 1.45^{\mathrm{a}}$ & $11.33 \pm 1.78^{\mathrm{a}}$ & $11.08 \pm 1.25^{\mathrm{a}}$ \\
\hline $\begin{array}{l}\text { NRT } \\
\text { (MIN.) }\end{array}$ & 0 & $5.63 \pm 1.13$ & $8.17 \pm 0.75$ & $6.79 \pm 1.25^{\mathrm{A}}$ & $5.87 \pm 1.39^{\mathrm{A}}$ \\
\hline $\begin{array}{l}\text { TVFA } \\
(\mathrm{mmol} / \mathrm{ml})\end{array}$ & 5 & $7.08 \pm 0.38$ & $13.15 \pm 1.69^{\mathrm{a}}$ & $12.93 \pm 1.53^{\mathrm{a}}$ & $12.67 \pm 1.62^{\mathrm{a}}$ \\
\hline $\begin{array}{l}\text { TPC } \\
\left(10^{5}\right)\end{array}$ & 0 & $22.20 \pm 1.26$ & $42.67 \pm 1.36^{\mathrm{a}}$ & $43.83 \pm 1.47^{\mathrm{a}}$ & $44.33 \pm 1.63^{\mathrm{a}}$ \\
\hline $\begin{array}{l}\text { TBC } \\
\left(10^{10}\right)\end{array}$ & 5 & $23.33 \pm 1.63$ & $36.83 \pm 1.47^{\mathrm{A}}$ & $32.33 \pm 2.47^{\mathrm{A}}$ & $29.17 \pm 1.83^{\mathrm{A}}$ \\
\hline $\begin{array}{l}\text { PM } \\
(+)\end{array}$ & 0 & $84.67 \pm 3.26$ & $62.32 \pm 2.26^{\mathrm{a}}$ & $61.07 \pm 2.63^{\mathrm{a}}$ & $63.37 \pm 3.50^{\mathrm{a}}$ \\
\hline & 5 & $87.17 \pm 3.07$ & $64.61 \pm 2.02$ & $70.18 \pm 3.05^{\mathrm{A}}$ & $74.73 \pm 4.60^{\mathrm{A}}$ \\
\hline & 5 & $3.27 \pm 0.18$ & $1.24 \pm 0.20^{\mathrm{a}}$ & $1.17 \pm 0.18^{\mathrm{a}}$ & $1.13 \pm 0.22^{\mathrm{a}}$ \\
\hline & 0 & $3.32 \pm 0.21$ & $1.72 \pm 0.31^{\mathrm{A}}$ & $2.26 \pm 0.19^{\mathrm{A}}$ & $2.36 \pm 0.29^{\mathrm{A}}$ \\
\hline & 5 & $15.97 \pm 0.78$ & $6.88 \pm 0.53^{\mathrm{a}}$ & $5.73 \pm 0.63^{\mathrm{a}}$ & $6.01 \pm 0.65^{\mathrm{a}}$ \\
\hline & 0 & $3.00 \pm 0.00$ & $0.83 \pm 0.41^{\mathrm{a}}$ & $0.83 \pm 41^{\mathrm{a}}$ & $0.67 \pm 0.52^{\mathrm{a}}$ \\
\hline & 5 & $3.00 \pm 0.00$ & $2.50 \pm 0.54^{\mathrm{A}}$ & $3.00 \pm 0.00^{\mathrm{A}}$ & $3.00 \pm 0.00^{\mathrm{A}}$ \\
\hline
\end{tabular}

$\mathrm{a}=$ Significant $(\mathrm{P} \leq 0.05)$ difference as compared to healthy control group within same row.

$\mathrm{A}=$ Significant $(\mathrm{P} \leq 0.05)$ difference as compared to Day 0 within same column. 
Table.2 Results of Haemato-Biochemical examination in different groups [Mean $\pm \mathrm{SE}$ ]

\begin{tabular}{|c|c|c|c|c|c|}
\hline Parameters & Day & Healthy control & Magnesium sulphate & Air dried RL & Lyophilized RL \\
\hline \multirow{2}{*}{$\begin{array}{l}\text { Haemoglobin } \\
(\mathrm{g} / \mathrm{dl})\end{array}$} & 0 & $10.23 \pm 0.29$ & $11.12 \pm 0.61$ & $10.98 \pm 0.61$ & $11.18 \pm 0.55$ \\
\hline & 5 & $10.36 \pm 0.31$ & $10.47 \pm 0.63$ & $10.10 \pm 0.73$ & $10.47 \pm 0.63$ \\
\hline \multirow{2}{*}{$\begin{array}{l}\text { PCV } \\
(\%)\end{array}$} & 0 & $32.00 \pm 3.00$ & $34.83 \pm 2.33$ & $35.50 \pm 3.16$ & $36.16 \pm 2.63$ \\
\hline & 5 & $31.61 \pm 2.84$ & $32.08 \pm 3.15$ & $30.84 \pm 3.71$ & $31.33 \pm 2.66$ \\
\hline \multirow{2}{*}{$\begin{array}{l}\text { TLC } \\
\left(10^{3}\right)\end{array}$} & 0 & $8.71 \pm 0.13$ & $9.65 \pm 0.22^{\mathrm{a}}$ & $9.85 \pm 0.22^{\mathrm{a}}$ & $9.60 \pm 0.21^{\mathrm{a}}$ \\
\hline & 5 & $8.78 \pm 0.16$ & $9.07 \pm 0.18^{\mathrm{A}}$ & $8.98 \pm 0.18^{\mathrm{A}}$ & $8.76 \pm 0.26^{\mathrm{A}}$ \\
\hline \multirow{2}{*}{$\begin{array}{l}\text { Neutrophils } \\
(\%)\end{array}$} & 0 & $38.33 \pm 3.78$ & $50.00 \pm 4.24^{\mathrm{a}}$ & $48.33 \pm 5.00^{\mathrm{a}}$ & $51.17 \pm 4.31^{\mathrm{a}}$ \\
\hline & 5 & $39.50 \pm 3.26$ & $44.50 \pm 4.46$ & $40.67 \pm 4.46$ & $41.84 \pm 4.66^{\mathrm{A}}$ \\
\hline \multirow{2}{*}{$\begin{array}{c}\text { Lymphocytes } \\
\text { (\%) }\end{array}$} & 0 & $55.50 \pm 2.62$ & $44.00 \pm 4.86^{\mathrm{a}}$ & $44.66 \pm 5.71^{\mathrm{a}}$ & $41.83 \pm 5.49^{\mathrm{a}}$ \\
\hline & 5 & $54.18 \pm 2.13$ & $48.16 \pm 5.87$ & $51.17 \pm 6.20$ & $50.83 \pm 6.88$ \\
\hline \multirow{2}{*}{$\begin{array}{l}\text { ALT } \\
\text { (IU/l) }\end{array}$} & 0 & $18.17 \pm 2.43$ & $24.43 \pm 0.75^{\mathrm{a}}$ & $23.50 \pm 0.43^{\mathrm{a}}$ & $23.67 \pm 0.39^{\mathrm{a}}$ \\
\hline & 5 & $18.39 \pm 3.03$ & $22.73 \pm 0.60$ & $21.27 \pm 0.58$ & $20.17 \pm 0.37^{\mathrm{A}}$ \\
\hline \multirow{2}{*}{$\begin{array}{l}\text { AST } \\
\text { (IU/l) }\end{array}$} & 0 & $125.97 \pm 8.86$ & $183.98 \pm 6.17^{\mathrm{a}}$ & $181.60 \pm 7.14^{\mathrm{a}}$ & $193.92 \pm 6.78^{a}$ \\
\hline & 5 & $123.16 \pm 5.05$ & $157.50 \pm 5.13^{\mathrm{A}}$ & $148.15 \pm 4.94^{\mathrm{A}}$ & $135.99 \pm 6.07^{\mathrm{A}}$ \\
\hline \multirow{2}{*}{$\begin{array}{l}\text { LDH } \\
\text { (IU/l) }\end{array}$} & 0 & $1198.18 \pm 27.48$ & $1407.17 \pm 21.51^{\mathrm{a}}$ & $1407.83 \pm 22.15^{\mathrm{a}}$ & $1411.15 \pm 19.64^{\mathrm{a}}$ \\
\hline & 5 & $1176.49 \pm 34.82$ & $1346.50 \pm 19.40^{\mathrm{A}}$ & $1283.13 \pm 18.48^{\mathrm{A}}$ & $1245.47 \pm 15.47^{\mathrm{A}}$ \\
\hline \multirow{2}{*}{$\begin{array}{l}\text { Glucose } \\
(\mathrm{mg} / \mathrm{dl})\end{array}$} & 0 & $56.41 \pm 2.42$ & $41.78 \pm 0.95^{\mathrm{a}}$ & $43.08 \pm 1.04^{\mathrm{a}}$ & $42.17 \pm 0.94^{\mathrm{a}}$ \\
\hline & 5 & $56.24 \pm 2.67$ & $48.57 \pm 1.11^{\mathrm{A}}$ & $51.13 \pm 1.56^{\mathrm{A}}$ & $52.88 \pm 1.34^{\mathrm{A}}$ \\
\hline \multirow{2}{*}{$\begin{array}{c}\text { Cholesterol } \\
(\mathrm{mg} / \mathrm{dl})\end{array}$} & 0 & $50.20 \pm 0.97$ & $49.83 \pm 1.02$ & $49.93 \pm 0.94$ & $50.54 \pm 1.12$ \\
\hline & 5 & $50.12 \pm 1.06$ & $50.83 \pm 1.13$ & $50.30 \pm 0.70$ & $50.65 \pm 1.00$ \\
\hline \multirow{2}{*}{$\begin{array}{l}\text { Proteins } \\
(\mathrm{g} / \mathrm{dl})\end{array}$} & 0 & $9.11 \pm 0.17$ & $8.97 \pm 1.12$ & $8.95 \pm 0.17$ & $9.00 \pm 0.16$ \\
\hline & 5 & $9.15 \pm 0.14$ & $9.06 \pm 0.13$ & $9.01 \pm 0.15$ & $9.07 \pm 0.12$ \\
\hline \multirow{2}{*}{$\begin{array}{l}\text { BUN } \\
(\mathrm{mg} / \mathrm{dl})\end{array}$} & 0 & $23.16 \pm 0.63$ & $27.58 \pm 1.12^{\mathrm{a}}$ & $27.80 \pm 1.07^{\mathrm{a}}$ & $27.08 \pm 0.88^{\mathrm{a}}$ \\
\hline & 5 & $23.01 \pm 0.45$ & $25.88 \pm 0.62^{\mathrm{A}}$ & $24.02 \pm 0.73^{\mathrm{A}}$ & $23.58 \pm 0.47^{\mathrm{A}}$ \\
\hline \multirow{2}{*}{$\begin{array}{l}\text { Calcium } \\
(\mathrm{mg} / \mathrm{dl})\end{array}$} & 0 & $10.08 \pm 0.08$ & $10.13 \pm 0.14$ & $10.03 \pm 0.07$ & $9.97 \pm 0.14$ \\
\hline & 5 & $9.94 \pm 0.16$ & $4.76 \pm 0.11$ & $9.96 \pm 0.14$ & $9.82 \pm 0.10$ \\
\hline \multirow{2}{*}{$\begin{array}{l}\text { Phosphorus } \\
\text { (mg/dl) }\end{array}$} & 0 & $4.97 \pm 0.14$ & $4.76 \pm 0.11$ & $4.85 \pm 0.13$ & $4.91 \pm 0.10$ \\
\hline & 5 & $4.87 \pm 0.05$ & $4.89 \pm 0.13$ & $4.78 \pm 0.16$ & $4.83 \pm 0.13$ \\
\hline
\end{tabular}

$\mathrm{a}=$ Significant $(\mathrm{P} \leq 0.05)$ difference as compared to healthy control group within same row.

$\mathrm{A}=$ Significant $(\mathrm{P} \leq 0.05)$ difference as compared to Day 0 within same column.

Table.3 Therapeutic evaluation scores (indicated in bracket) based on number of buffaloes suffering from simple indigestion post treatment in different groups

\begin{tabular}{|c|c|c|c|}
\hline Days post treatment & Magnesium sulphate & Air dried RL & Lyophilized RL \\
\hline 0 & 6 & 6 & 6 \\
\hline 1 & 6 & 6 & 6 \\
\hline 2 & $5(.17)$ & $4(.33)$ & $4(.33)$ \\
\hline 3 & $4(.20)$ & $3(.25)$ & $2(.50)$ \\
\hline 4 & $2(.50)$ & $1(.66)$ & $1(.50)$ \\
\hline 5 & $1(.50)$ & $0(1.0)$ & $0(1.0)$ \\
\hline Score & $(\mathbf{1 . 3 7})$ & $\mathbf{( 2 . 2 4 )}$ & $\mathbf{( 2 . 3 3 )}$ \\
\hline
\end{tabular}


The Protozoan motility decreases whenever there is a reduction in rumen $\mathrm{pH}$ (Steen, 2001) and during underfeeding or starvation (Dirksen, 1969). It had been shown that the efficiency of growth of predominant rumen bacteria vary considerably with changes in rumen $\mathrm{pH}$. Cellulolytic and methanogenic bacteria were severely affected once the rumen $\mathrm{pH}$ falls below 6.0 (Mcdonald et al., 1995).

Haemoglobin and Packed Cell Volume did not show any significant difference $(\mathrm{P}>0.05)$ before and after treatment. Findings were similar to Kasaralikar et al., (2014), however Mohan et al., (2015) found haemoglobin and $\mathrm{PCV}$ were increased in cases of indigestion as a result of haemo-concentration due to increased osmolarity of rumen contents which withdraws fluid from intravascular compartments (Huber, 1971 mohan 2015). Hematological studies revealed leukocytosis, neutrophilia and lymphocytopenia in the buffaloes suffering from simple indigestion. Stocker et al., (1999) also reported leukocytosis in animals suffering from indigestion, which could be due to inflammatory response to gastrointestinal stasis leading to absorption of toxins into circulation (Garry, 2002). Hussain and Uppal (2012) also reported neutrophilia and lymphocytopenia in animals suffering from ruminal disorders. Neutrophilia might have resulted from chronic irritation of the forestomach wall by impacted feed materials, leaving the wall exposed to secondary infection, which resulted in inflammation (Hailat et al., 1996). Decreased lymphocytes could be due to release of corticosteroid as a result of stress (Feldman et al., 2000).

\section{Acknowledgements}

The authors would like to thanks Dean, College of Veterinary and Animal Sciences, GB Pant University of Agriculture \&
Technology, Uttarakhand, India, for providing the research facilities.

\section{References}

Balain DS. Inflow and outflow of buffalo germplasm resources and their global contribution. National Bureau of Animal Genetic Resources (ICAR), Karnal 1999; 12.

Belknap EB and Navarre CB. "Differentiation of gastrointestinal diseases in adult cattle". Vet. Clin. North Am. Food Anim. Pract., 2000; 16: 59.

Bhatta R, Tajima K and Kurihara M. Influence of temperature and $\mathrm{pH}$ on fermentation pattern and methane production in the rumen simulating fermenter (RUSITEC). Asian-Aust. J. of Ani. Sci., 2006; 19: 37680.

Chakrabarti A. Textbook of Clinical Veterinary Medicine. Third Edn. Kalyani Publishers, Ludhiana (India); 2006.

Department of Animal Husbandry, Dairying and Fisheries (DAHD), Govt. of India. Ministry of Agriculture, 19 Livestock Census-2012 All India Report. New Delhi, Manager of Publications, 2014; 5-23.

Dirksen G. Is the "methylen blue-reductionprobe" usable as quick-test for clinical examination of rumen fluid? Dtsch. Tierärztl. Wschr., 1969; 76: 305-309.

Feldman BF, Zinkl JG and Jain NC. Schalm's Veterinary Haematology. $5^{\text {th }}$ edn. Lee and Febiger, Philadelphia; 2000.

Fouda TA. Clinical and biochemical studies on the primary ruminal dysfunction in sheep. Ph.D. Thesis (Veterinary Medicine), Faculty of Veterinary Medicine, Suez Canal University, 1995.

Garry FB. Indigestion in ruminants. In: B. P. Smith (ed.): Large animal internal medicine 2nd ed. Mosby, St. Louis and Baltimore; 2002.

Hailat N, Nouth S, Al-Darraji A, Lafi S, Al-Ani $\mathrm{F}$ and Al-Manjali A. Prevalence and pathology of foreign bodies (plastic) in Awassi sheep in Jordan. Small Rum. Res., 
1996; 24: 43-48.

Huber TL. Effect of acute indigestion on compartmental water volumes and osmolarity in sheep. Amer. J. Vet. Res., 1971; 32: 887.

Hussain SA and Uppal SK. Rumen impaction in buffaloes A haemato-biochemical study. Ind. J. of Ani. Sci., 2012; 82(4): 369-373.

Jain, N.C. 1986. Schalm's Veterinary Haematology, $4^{\text {th }}$ ed. Lea and Febiger, Philadelphia; 1986.

Kasaralikar VR, Patil NA, Ravikanth K, Thakur $A$ and Maini S. Clinico-therapeutic evaluation of Ruchamax and Ruchamax-N in various digestive disorders and restoration of normal ruminal function. Int. J. of Phytopharm., 2014; 4(2): 67-69.

McDonald P, Edwards RA and Greehalgh JTD. Animal Nutrition $5^{\text {th }}$ ed. Longman, London; 1995.

Mohan GC, Kumar AC and Naik BR. Therapeutic efficacy of poly-herbal formulations and heterologous cud transplantation with probiotics in ameliorating simple indigestion in buffaloes. Int. J. Pharm. Bio. Sci., 2015; 6(1): $38-46$.

Nicholus RE and Penn K. Simple methods for the detection of unfavourable changes in rumen ingesta. J. Amer. Vet. Med. Assoc., 1958; 133: 275-277.

Radostits OM, Gay CC, Hinchcliff KW and Constable. PD Ed., Veterinary Medicine: A textbook of cattle, horses, sheep, pigs and goats, 10th Edition, Saunders Publishers;
2006.

Ratib MH. Correlation between some ruminal contents and the respective morphological changes in sheep in Assiut governorate. M.V.Sc. Fac. of Vet. Medicine, Assiut. University, 2001.

Resali DP. Recent trends in buffalo production in Nepal In: A review, Buffalo News letter, Bulletin of The FAO Inter-Regional Cooperative Research Network on Buffalo 2000; 6-10.

Sharma N. Collection and examination of rumen fluid. In: Clinical Veterinary Medicine (Practical Manual Series), New India Publishing; 2009.

Shrestha SK and Shresth, NP. Genetic improvement of buffalo. In: First national workshop on Animal Genetic Resources, Genetic improvement of Domestic animals, NARC, Kathmandu, 1998; 98102.

Singh N, Akbar MA, Kumari R and Khanna BM. Effect of some treatment on ruminal environment and milk production in clinical cases of indigestion in buffaloes. Ind. Vet. Med. J., 1996; 20: 115-118.

Steen A. Field study of dairy cows with reduced appetite in early lactation: clinical examinations, blood and rumen fluid analyses. Acta. Vet. Scand., 2001; 42: 219228.

Stocker H, Lutz H, Rusch P. Clinical, haematological and biochemical findings in milk-fed calves with chronic indigestion. Vet. Rec.1999; 145: 307-311.

\section{How to cite this article:}

Arpit Tyagi, Richa Arora, S. Shekhar, V.S. Rajora and Niddhi Arora. 2018. Therapeutic Assessment of Dried Rumen Liquor Preparations in Cases of Simple Indigestion in Buffaloes. Int.J.Curr.Microbiol.App.Sci. 7(07): 3769-3777. doi: https://doi.org/10.20546/ijcmas.2018.707.437 